\title{
Theoretical and Empirical Foundations of Energy Production Efficiency Activity
}

\author{
Luigi Aldieri ${ }^{1}$, Concetto Paolo Vinci ${ }^{2}$ \\ ${ }^{1}$ Parthenope University of Naples, Italy \\ ${ }^{2}$ University of Salerno, Italy \\ Correspondence: Luigi Aldieri, Parthenope University of Naples, Italy.
}

Received: June 27, 2017

doi:10.5539/ibr.v10n9p39
Accepted: July 28, 2017

Online Published: August 1,2017

URL: https://doi.org/10.5539/ibr.v10n9p39

\begin{abstract}
The objective of this paper is to explore the energy production efficiency activity of large R\&D-intensive firms. Research methodology follows two steps: first, we describe the theoretical background through a firm level model and, second, we develop econometric techniques that explore spatial spillovers and deal with the endogeneity of the explanatory variables. The findings show a significant effect of energy innovation externalities on firms' environmental performance.
\end{abstract}

Keywords: innovation; energy technology spillovers; environmental proximity

JEL codes: O32; O33; Q5

\section{Introduction}

The transition to a low-carbon competitive economy is a central challenge of our time. The success of this aim would assure new economic opportunities, prosperity, welfare and growth, while the eventual failure may put our well being at stake. All countries need to step up their investments in energy efficiency and renewable technologies. According to Porter (1991), strict environmental regulations could enhance the competitive advantage against rivals.

The existence of energy spillovers as a market failure provides support to the Porter hypothesis (Ambec et al. 2013). Indeed, Mohr (2002) finds that firms may switch to equilibrium with higher R\&D investments, when there are technology spillovers to competitors, while Gans (2012) explains that more rigid climate policies will not produce necessarily more innovation. Also Greaker (2003) identifies technological spillovers as a theoretical prediction of Porter hypothesis. Hence, knowledge spillovers play a potentially important role for innovation and productivity in environmental technologies. However, we lack empirical studies about knowledge spillovers in such technologies at the firm level, as discussed in Hoppmann (2016).

To close this gap, in this article we investigate the effects of spillovers from innovation in energy production efficiency activities on environmental performance for American, Japanese and European firms. In particular, we distinguish the intra-industry spillovers (Marshall, 1890; Arrow, 1962; Romer, 1986) and inter-industry externalities (Jacobs, 1969).

The paper is structured as follows. Section 2 explores the spatial energetic spillovers of firms. Section 3 illustrates the theoretical core of the paper. Data and empirical framework are presented in the section 4 . Section 5 evidences the results and final section discusses the findings and concludes.

\section{Energy Innovation and Spatial Anal ysis within the Triad}

In order to investigate energetic innovation and its distribution, we use particular econometric tools (Pisati, 2008; Crow, 2015; Kondo, 2015 and 2016).

In Table 1, we illustrate energy patents with IPC selected by the OECD or the World Intellectual Property Organization (WIPO), as in Marin and Lotti (2016). 
Table 1. Energy patent classes

\begin{tabular}{|c|c|c|}
\hline $\begin{array}{c}\text { Macro } \\
\text { category }\end{array}$ & Sub-category & IPC \\
\hline \multirow{11}{*}{ Energy } & Integrated emissions control & F02B, F02M, F01N, F02D, G01M, F02P \\
\hline & Post-combustion emissions control & F01M, F01N, F02B, F02D, F02M, G01M, B01D, B01J, B60, B62D \\
\hline & $\begin{array}{l}\text { Technologies specific to propulsion } \\
\text { using electric motor }\end{array}$ & $\mathrm{B} 60 \mathrm{~K}, \mathrm{~B} 60 \mathrm{~L}, \mathrm{~B} 60 \mathrm{R}, \mathrm{B} 60 \mathrm{~S}, \mathrm{~B} 60 \mathrm{~W}$ \\
\hline & $\begin{array}{l}\text { Technologies specific to hybrid } \\
\text { propulsion }\end{array}$ & $\mathrm{B} 60 \mathrm{~K}, \mathrm{~B} 60 \mathrm{~W}$ \\
\hline & Fuel efficiency-improving vehicle & $\mathrm{B} 62 \mathrm{D}, \mathrm{B} 60 \mathrm{C}, \mathrm{B} 60 \mathrm{~T}, \mathrm{~B} 60 \mathrm{G}, \mathrm{B} 60 \mathrm{~K}, \mathrm{~B} 60 \mathrm{~W}$ \\
\hline & Insulation & F04B, E06B \\
\hline & Heating & F24D \\
\hline & Lighting & H01J, H05B \\
\hline & Wind energy & F03D, H02K, B63B, E04H, B60K, B60L, B63H \\
\hline & Solar energy & $\begin{array}{l}\text { H01L, H01G, H02N, C01B, C23C, C30B, G05F, F21L, F21S, H02J, } \\
\text { H01H, H01M, F24J, E04D, F22B, F25B, F26B, G02B }\end{array}$ \\
\hline & Geothermal energy & F01K, F24F, F24J, H02N, F25B, F03G \\
\hline
\end{tabular}

Our aim is to test for the presence of both global and local spatial autocorrelation through the use of Moran index and Moran scatterplot, respectively.

Moran's I test has the following form (Moran, 1950; Anselin, 1995): $I=\frac{z \prime W z}{z^{\prime} z}$, where $\mathrm{z}$ is an $\mathrm{N}-$ vector of standardized energy patents, $\mathrm{W}$ is an $\mathrm{N} \times \mathrm{N}$ row-standardized spatial weight matrix ${ }^{1}$ and $\mathrm{N}$ is the number of observations. This study also presents Moran scatterplots, which depict how the geographical units depend on each other (Anselin, 1995).

As we may observe in Tables 2 and 4, the positive value of Moran-I indicates positive spatial autocorrelation across the American and European regions, that is, regions neighboring a region with high energy patents also show high energetic innovation rates, while in Japan (Table 3) we do not find a significant autocorrelation across regions.

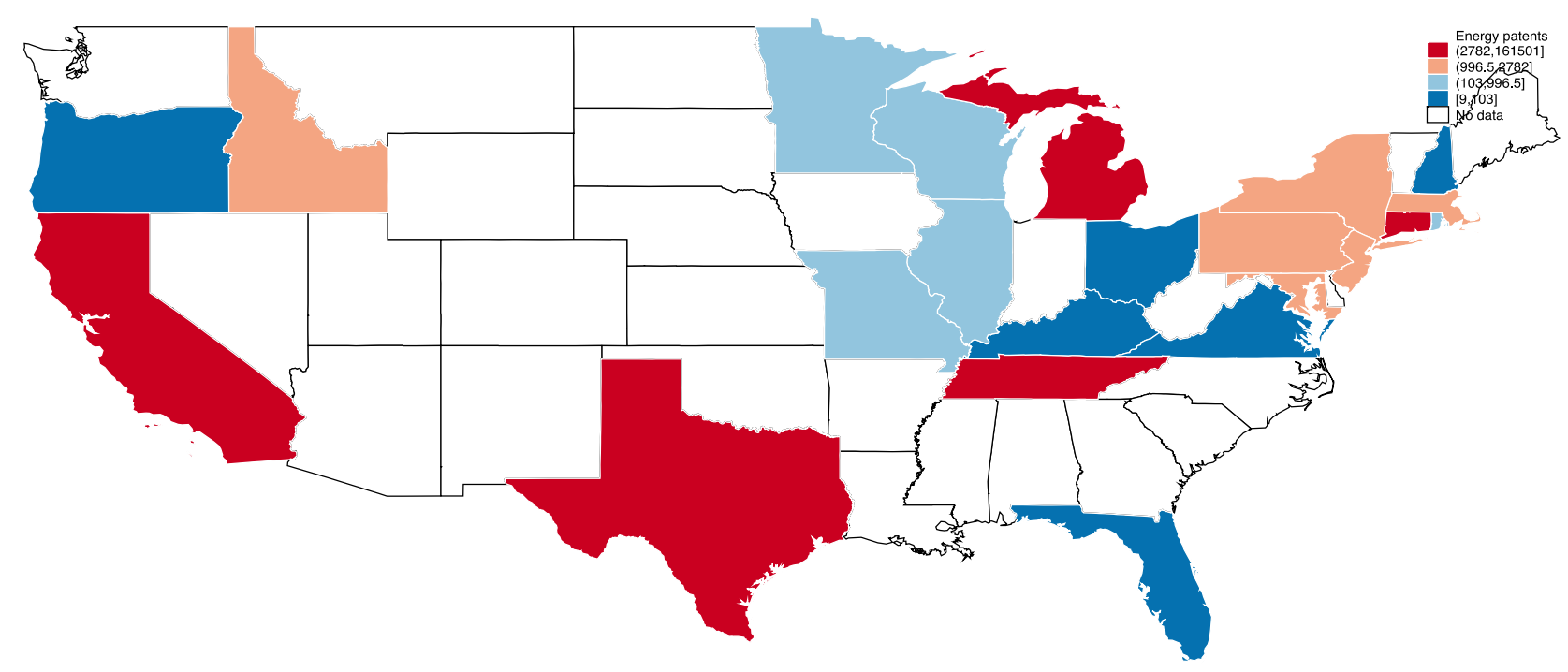

Figure 1. Energy patents in the USA

In Figure 1, where the USA country is clustered into 51 states (see Appendix), we may observe that New Jersey, Connecticut, Michigan, California and Tennessee exhibit the hot spots, while New Hampshire, Ohio, Kentucky, Virginia, Oregon and Florida display the cold spots.

\footnotetext{
${ }^{1}$ We assume that spatial spillovers exists only within a distance of $300 \mathrm{~km}$ (Bottazzi and Peri, 2003).
} 
Table 2. Moran scatterplot for the USA

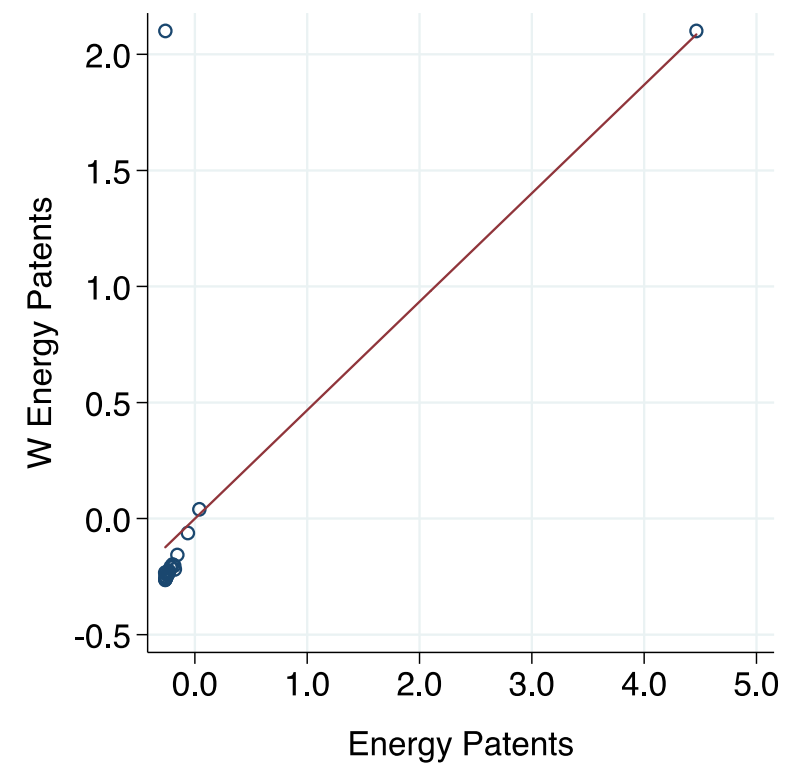

Note: Moran-I test: $0.467, \mathrm{p}$-value: 0.000

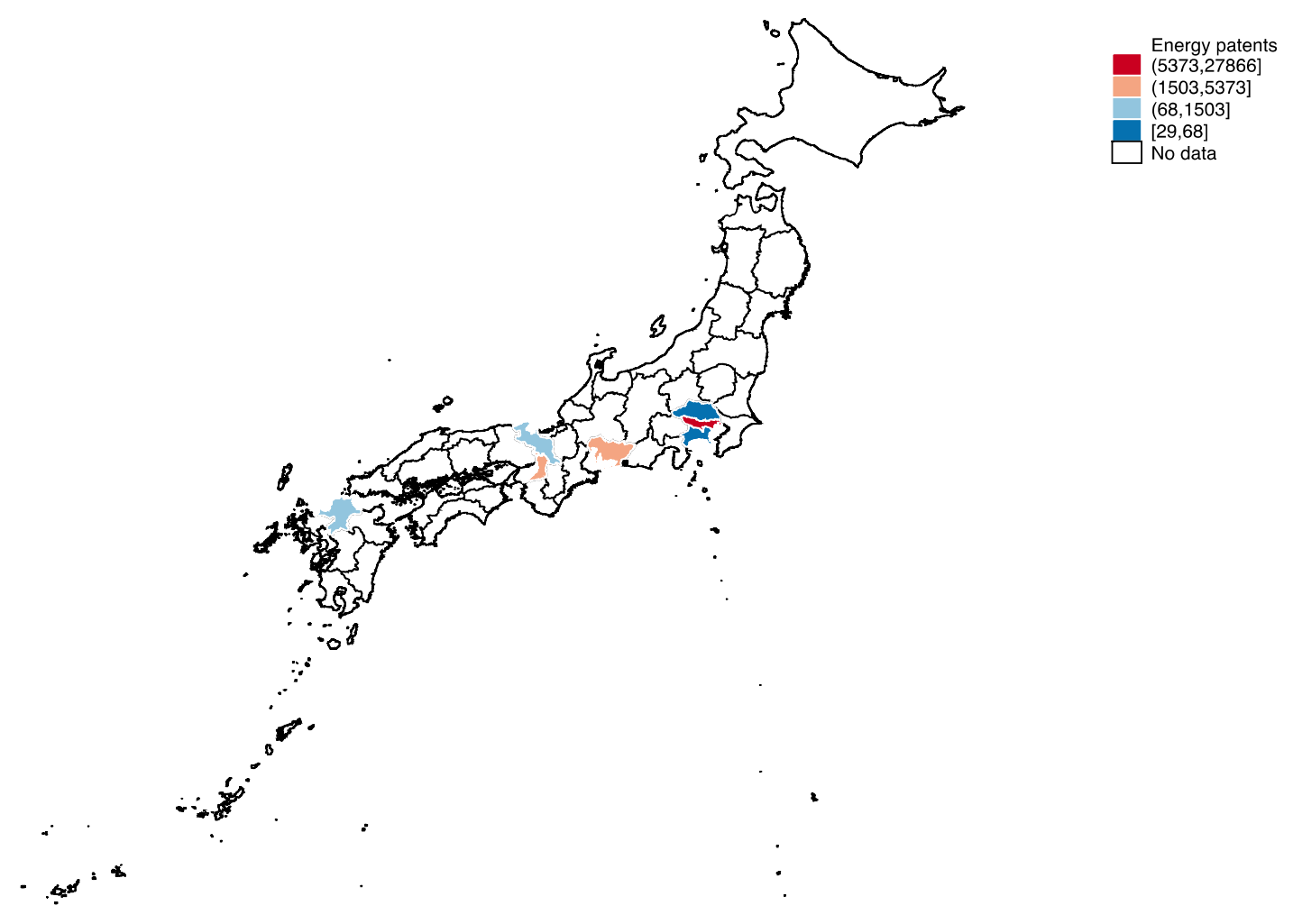

Figure 2. Energy patents in Japan 
In Figure 2, where Japan country is clustered into 47 prefectures (see Appendix), we observe that Tokyo exhibits hot spots, while Kanagawa and Saitama display cold spots.

Table 3. Moran Scatterplot for Japan

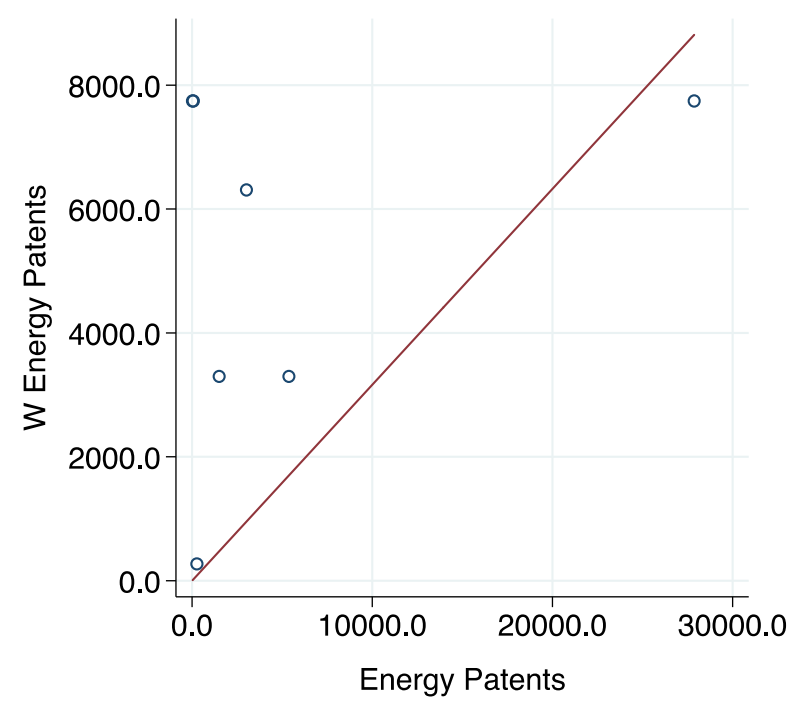

Note: Moran-I test: 0.099, p-value: 0.460

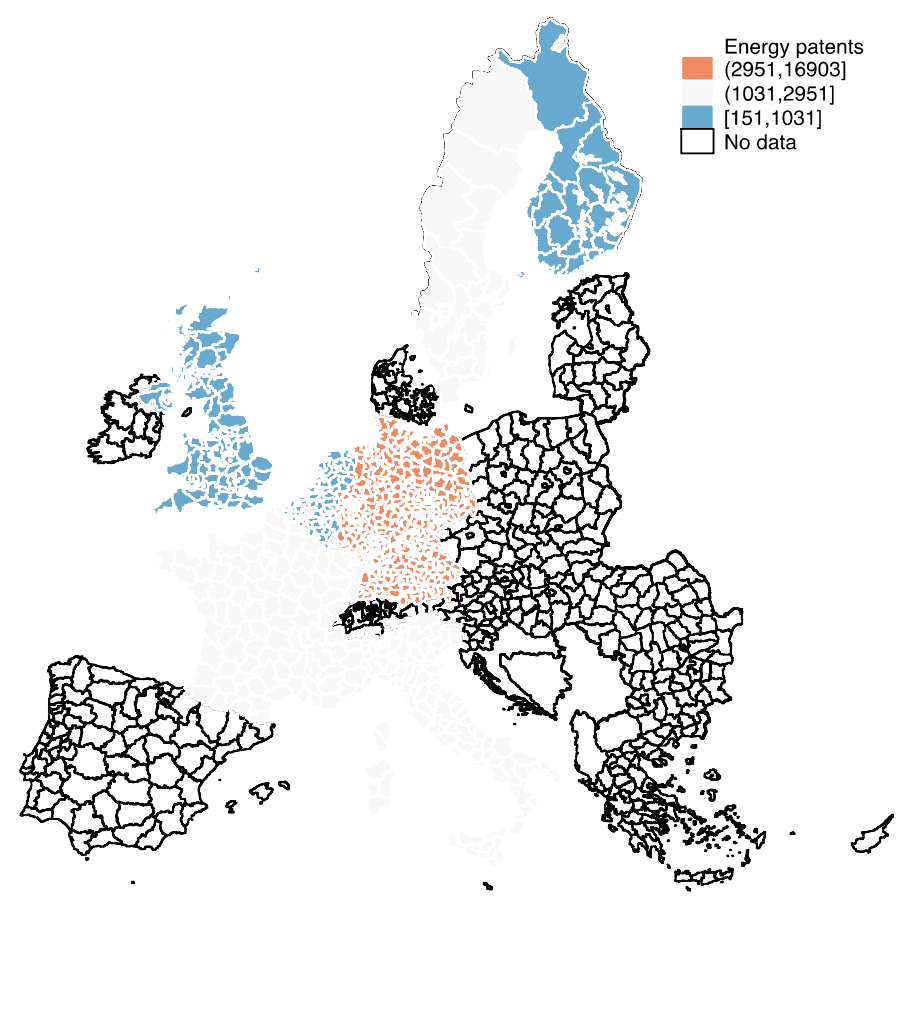

Figure 3. Energy patents in Europe

In Figure 3, where Europe is clustered into 42 countries (see Appendix), we observe that Germany exhibits hot spots, while Belgium displays cold spots. 
Table 4. Moran Scatterplot for Europe

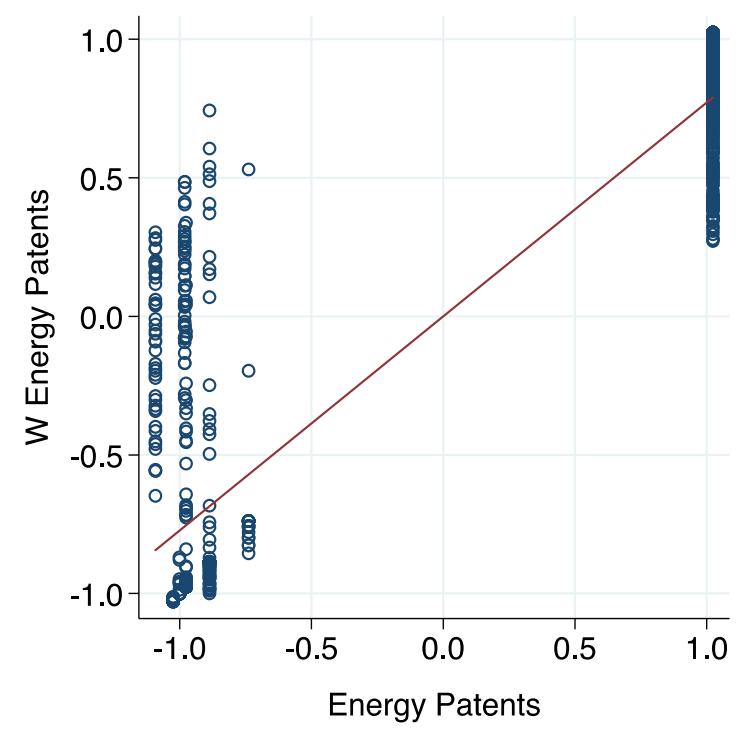

Note: Moran-I test: 0.772 , p-value: 0.000

\section{Theoretical Framework}

In order to better specify the relationships and sources of our empirical framework, this section develops a multi-region multi-sector theoretical model, and focuses on aspects related to different types of green energy (wind, solar and geothermal energy, integrated emissions control, lightning to quote some) knowledge diffusion and accumulation. Following Bretschger et al. (2017), in each region at time $t$ final production $Y_{i r}$ in sector $i$ may be taken as the combination of two different outputs from two different production techniques: a first $Y_{\text {igrt }}$ where knowledge diffusion leads to a "greening" of economies improving the different types of green energy (wind, solar and geothermal energy, integrated emissions control, lightning to quote some), a second one $Y_{\text {inrt }}$ where companies' green investments are quite irrelevant. Knowledge diffusion, together with other targets such as water pollution abatement and solid waste collection, may have an important role for a drop of global climate policies cost in most of emerging countries. The final production $Y_{i r}$ may be written as follows:

$$
Y_{\text {irt }}=Y\left[\theta Y_{\text {igrt }} ;(1-\theta) Y_{\text {inrt }}\right] \quad \text { with } \theta \in[0,1]
$$

The green output $Y_{\text {igrt }}$ may be taken as a sector-specific output $Q_{\text {igrt }}$ and a composite input from other sector $B_{t}^{2}$ :

$$
Y_{i g r t}=Y_{g}\left[\alpha Q_{i g r t} ;(1-\alpha) B_{t}\right]
$$

where $\alpha \in[0,1]$ is a share parameter. Output $Q_{\text {igrt }}$ is produced by combining varieties of intermediate composite goods $x_{i g j}$ according to:

$$
Q_{i g r t}=Q\left(\int_{j=0}^{J_{i r t}} x_{i g j r t} d j\right)
$$

where $J_{i r t}$ measures the total number of intermediate varieties in sector $i$ region $r$ at time $t$. If we assume symmetric production of intermediate composite goods: $x_{i g j r t}=x_{i g r t}$ we will have: $\chi_{i g t}=J_{i r t} x_{i g r t}$ and

2 It's only for simplicity that region and sector indices are omitted. 
(2) may be written as:

$$
Q_{i g r t}=Q\left(\chi_{i g t}\right)
$$

from inspection of which we will observe that $Q_{i g r t}$ may grow either by yielding more quantity $(x)$ per firm, given $(J)$, or by increasing the whole number of intermediate varieties. In this light, as well emphasized in Bretschger et al. (2017) each single variety is produced by a precise company and every new firm requires additional knowledge capital to be active. Different interpretations may be attributed to $J$ :

- a measure of knowledge green Capital,

- the number of intermediate varieties,

- total of intermediate Companies.

Let's now introduce a mechanism of knowledge accumulation and diffusion. We will assume that knowledge capital at time $t$ in region $r$ depends on investment at time $t-1 I_{g r t-1}$, knowledge stock at time $t-1$, and knowledge increment at time $t-1 \Delta J_{\text {irt-1 }}$ :

$$
J_{i r t}=I_{g r t-1}+(1-\delta)\left(\Delta J_{i r t-1}+J_{i r t-1}\right)
$$

with $\delta$ measuring a constant knowledge depreciation rate. In order to extend the knowledge diffusion to cover inter-sectorial domestic and foreign intra-sectorial knowledge spillovers, as in Bretschger et al. (2017) we can take assume:

$$
\begin{gathered}
\Delta J_{i r t}=f\left(J_{i r t} ; J_{i r t}^{B} ; J_{i r t}^{C}\right) \\
J_{i r t}^{B}=\sum_{h \neq i} J_{h r t} \\
J_{i r t}^{C}=\sum_{s \neq r} J_{i s t}
\end{gathered}
$$

where $s$ and $h$ are regional and sectorial indexes, while $J_{i r t}^{B}$ and $J_{i r t}^{C}$ stand for respectively domestic inter-sectorial and foreign intra-sectorial knowledge stocks. By combining the above conditions we may easily derive what follows:

$$
J_{i r t}=J\left(J_{i r t-1} ; J_{i r t-1}^{B} ; J_{i r t-1}^{C}\right)
$$

Since intermediate goods $x_{i g r t}$ are produced by combining labor $L_{i g r t}$, energy $E_{i g r t}$ and physical capital $C_{i g r t}$, and may be:

$$
x_{i g r t}=x\left(L_{i g r t}, E_{i g r t}, C_{i g r t}\right)
$$

condition (2) will be revised as:

$$
Y_{\text {igrt }}=Y_{g}\left\{\alpha Q\left[J\left(J_{\text {irt-1 }} ; J_{\text {irt }-1}^{B} ; J_{\text {irt }-1}^{C}\right) x\left(L_{\text {igrt }}, E_{\text {igrt }}, C_{\text {igrt }}\right)\right] ;(1-\alpha) B_{t}\right\}
$$

Shifting our attention to $Y_{\text {inrt }}$, with irrelevant companies' green investments, we can assume that 
production derive by the combination of labor $L_{i n r t}$, energy $E_{i n r t}$, physical capital $C_{i n r t}$, and finally knowledge capital $K_{\text {inrt }}$ depending on knowledge green Capital $K_{\text {inrt }}=K_{n}\left(J_{\text {irt }}\right)$ we may write that:

$$
Y_{\text {inrt }}=Y_{n}\left[L_{i n r t}, E_{\text {inrt }}, C_{\text {inrt }}, K_{n}\left(J_{\text {irt }}\right)\right]
$$

Lastly condition (1) will turn into:

$$
\begin{aligned}
& Y_{i r t}=Y\left\{\theta Y_{g}\left\{\alpha Q\left[J\left(J_{i r t-1} ; J_{i r t-1}^{B} ; J_{\text {irt-1 }}^{C}\right) x\left(L_{\text {igrt }}, E_{\text {igrt }}, C_{i g r t}\right)\right] ;(1-\alpha) B_{t}\right\} ;(1\right. \\
& \left.\quad-\theta) Y_{n}\left[L_{\text {inrt }}, E_{\text {inrt }}, C_{\text {inrt }}, K_{n}\left(J\left(J_{\text {irt-1 }} ; J_{\text {irt-1 }}^{B} ; J_{\text {irt }-1}^{C}\right)\right)\right]\right\}
\end{aligned}
$$

Inspection of condition (13), and the premise according to which each sector has a production structure as the one depicted in Figure 4, take us to suggest that Knowledge diffusion leading to a greening process of economies depends on accessibility and absorptive capacity, and conclude with the following testable result:

\section{Result}

$[\mathbf{H}]:$ The effect of spillovers due to diversified green technology fields concerning energy production efficiency activity (Jacobian externalities) on firms' environmental performance is positive.

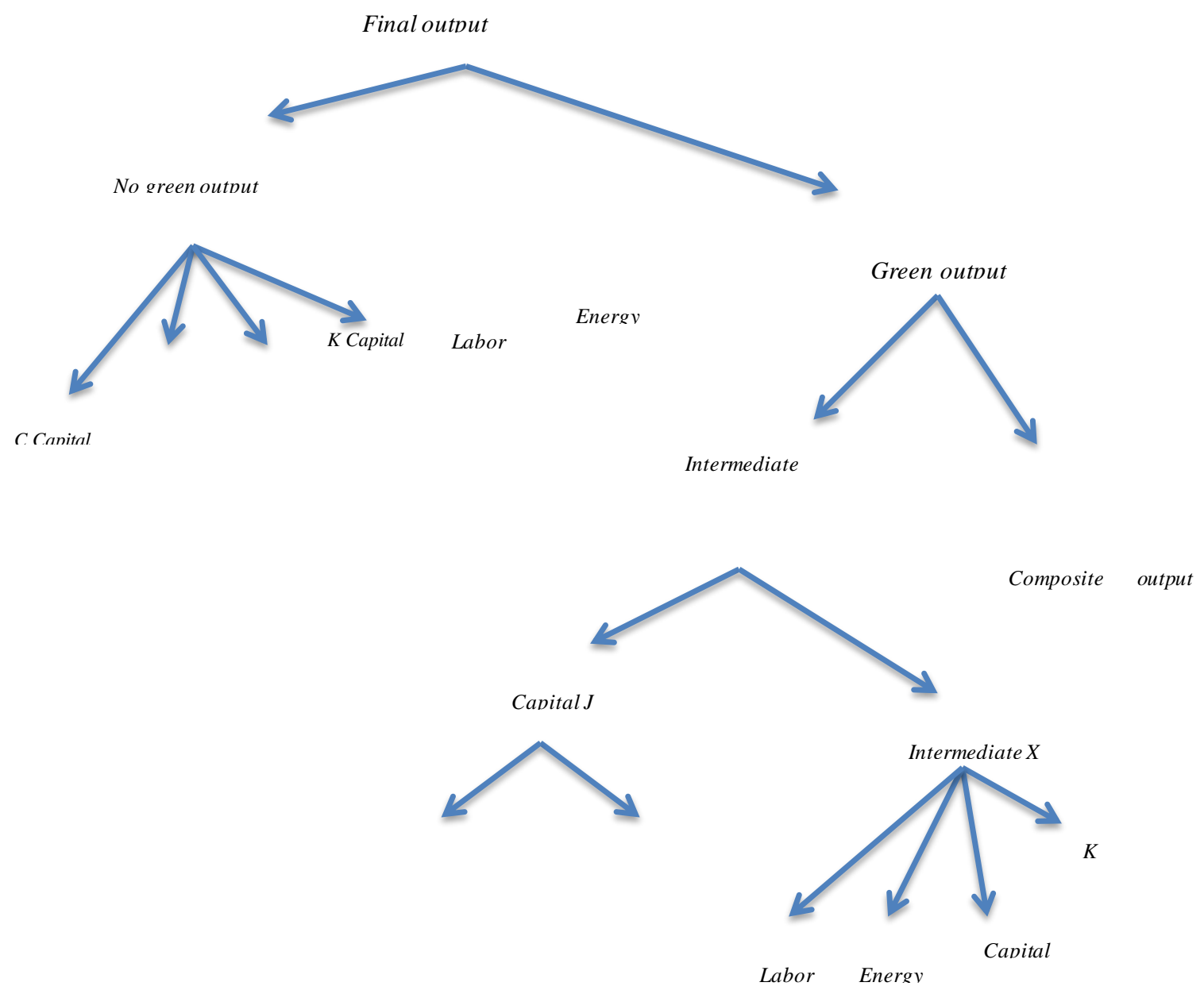

Figure 4. Firms' Production structure 


\section{Data and Methodology}

OECD, REGPAT database (2017) is employed. We match the name of the same 240 firms to applicant's name from European Commission (2013), as in Aldieri (2013). Another source is the Environmental Accounts providing $\mathrm{CO} 2$ emissions variable by country and by year in the World Input Output Database (WIOD).

In order to measure the effect of energy technology on firms' environmental performance, we develop the following extended Cobb-Douglas production function:

$$
\operatorname{lnSCO} 2=\alpha_{i}+\lambda_{t}+\beta_{1} \ln L_{i t}+\beta_{2} \ln C_{i t}+\beta_{3} \ln K_{i t}+\gamma_{1} \operatorname{lnINTRA_{it}}+\gamma_{2} \operatorname{lnINTER_{it}}+\varepsilon_{i t}
$$

where $\ln =$ natural logarithm;

$S C O 2_{i t}=$ Environmental performance measured as ratio between net sales and $\mathrm{CO} 2$ for firm $i$ and year $\mathrm{t}$;

$C_{i t}=$ physical capital stock for firm $i$ and year $t$;

$L_{i t}=$ number of employees for firm $i$ and year $t$;

$K_{i t}=\mathrm{R} \& \mathrm{D}$ capital stock of firm $i$ and year $t$

$\alpha_{i}=$ firm's fixed effects;

$\lambda_{t}=$ set of time dummies;

$I N T R A_{i t}=$ vector of externalities relative to firms belonged to the same industry, computed on the basis of environmental proximity. This is the Jaffe's procedure (Aldieri and Cincera, 2009) with energy patents;

$I N T E R_{i t}=$ vector of externalities relative to firms of different industries, as for the previous variable;

$\beta, \gamma=$ vectors of parameters;

$\varepsilon_{i t}=$ disturbance term.

The previous extended version Cobb-Douglas production function to consider also the spillover components is in line with the relative empirical literature (as discussed in Aldieri and Cincera, 2009; Aldieri and Vinci, 2017a and 2017b).

In Table 5, we display the summary statistics of our sample.

Table 5. Summary statistics

\begin{tabular}{ccc}
\hline Variable & Mean $^{\mathrm{a}}$ & Std. Dev. \\
\hline $\operatorname{lnSCO} 2$ & 21.68 & 4.021 \\
$\operatorname{lnC}$ & 7.49 & 1.584 \\
$\operatorname{lnL}$ & 9.97 & 1.360 \\
LnK & 7.15 & 1.426 \\
$\operatorname{lnINTRA}$ & 3.07 & 6.272 \\
$\operatorname{lnINTER}$ & 3.37 & 6.705 \\
\hline
\end{tabular}

Note: a) 1837 observations;

\section{Results and Discussion}

In order to address the endogeneity of the explanatory variables, we estimate equation (14) using the Generalized Method of Moments (GMM) 3 estimator.

In Table 6, we show the effects of intra-industry spillovers (INTRA) and inter-industry spillovers (INTER) on firms' environmental performance. Moreover, we include lagged energy spillover components by a year to mitigate contemporaneous effects.

\footnotetext{
${ }^{3}$ See Arellano and Bover (1995) and Blundell and Bond (1998).
} 
Table 6. Environmental Performance of Spillovers effects: GMM estimates

\begin{tabular}{|c|c|c|c|}
\hline Dependent variable: $\Delta \ln \mathrm{SCO} 2_{\mathrm{t}}$ & Estimate & & S.E. ${ }^{\mathrm{a}}$ \\
\hline$\Delta \operatorname{lnSCO} 2(\mathrm{t}-1)$ & $1.03 * * *$ & & $(0.068)$ \\
\hline$\Delta \operatorname{lnL}$ & $0.93^{* * *}$ & & $(0.145)$ \\
\hline$\Delta \ln C$ & -0.35 & & $(0.153)$ \\
\hline$\Delta \ln K$ & -0.43 & & $(0.154)$ \\
\hline$\Delta \operatorname{lnINTRA}(\mathrm{t}-1)$ & $-0.29 *$ & & $(0.173)$ \\
\hline$\Delta \ln I N T E R(t-1)$ & $0.25^{*}$ & & $(0.152)$ \\
\hline $\operatorname{AR}(1)^{\mathrm{c}}$ test & $\mathrm{z}=-5.42$ & $\mathrm{p}>\mathrm{z}=0.000$ & \\
\hline $\mathrm{AR}(2)$ test & $\mathrm{z}=0.41$ & $\mathrm{p}>\mathrm{z}=0.679$ & \\
\hline Hansen $^{\mathrm{b}}: \chi^{2}(83)=99.56$ & & & [0.104] \\
\hline
\end{tabular}

Notes: a: heteroskedastic-consistent standard errors; $b$ : Hansen test of over-identifying restrictions, $\mathrm{p}$-value in squared brackets; c: $\operatorname{AR}(1)$ and $\operatorname{AR}(2)$ are tests for first- and second-order serial correlation; ***, **, coefficient significant at the $1 \%, 5 \%$ level respectively. Country, time and industry dummies included. Endogenous variables are physical capital, labor, R\&D capital stock and spillovers. Instruments are lagged values (2-9) of all explanatory variables.

In order to identify the elements that change over time but not over the cross-sectional dimension of the sample, we include also time, country and industry dummies. The results of Hansen tests do not reject the null hypothesis of valid instruments, supporting the no-correlation of the instruments with the error term.

As far as our findings are concerned, intra-industry externalities (INTRA) have a negative effect, while the inter-industry externalities has a positive one, in line with the expected sign of the variables included in the model. Indeed, the diversification process in green activities leads to important environmental performance improvements. This result could be interpreted as an important instrument of policy makers: more additional incentives are required to improve the complementarity between the energetic sectors.

\section{Concluding Remarks}

The objective of this paper is to explore the energy production efficiency activity of large R\&D-intensive firms. An original Environmental proximity matrix is constructed, on the basis of technological vectors for each firm. Since there are few empirical studies about knowledge spillovers in such technologies at the firm level, as discussed in Hoppmann (2016), we close this gap by investigating the effects of spillovers from innovation in energy production efficiency activities on environmental performance for large international firms. In particular, we distinguish the intra-industry externalities and inter-industry externalities. To address the endogeneity of the explanatory variables, we run the Generalized Method of Moments (GMM)estimator. From the empirical results, we may observe that energy intra-industry spillovers (INTRA) have a negative impact on environmental performance, while the energy inter-industry components (INTER) have a positive effect. This finding is useful as a relevant policy maker instrument: the full sustainability achievement requires more incentives to complete the integration between energy technology fields.

However, further research on this topic is needed. The analysis should focus on factors that affect heterogeneity in technology spillovers effects both in spatial context and on the basis of indus trial sectors.

\section{References}

Aldieri, L. (2013). Knowledge technological proximity: evidence from US and European patents. Economics of Innovation and New Technology, 22, 807-819. https://doi.org/10.1080/10438599.2013.788838

Aldieri, L., \& Cincera, M. (2009). Geographic and technological R\&D spillovers within the Triad: micro evidence from US patents. The Journal of Technology Transfer, 34(2), 196-211. https://doi.org/10.1007/s10961-007-9065-8

Aldieri, L., \& Vinci C. P. (2017b). Firms' Innovation in Waste Management and Land Fertilizers within the Triad. International Journal of Business and Management, 12 (8), 120-130. https://doi.org/10.5539/ijbm.v12n8p120

Aldieri, L., \& Vinci, C. P. (2017a). The Role of Technology Spillovers in the Process of Water Pollution Abatement for Large International Firms. Sustainability, 9(5), 868. https://doi.org/10.3390/su9050868

Ambec, S., Cohen, M. A., Elgie, S. \& Lanoie, P. (2013). The Porter Hypothesis at 20: Can Environmental Regulation Enhance Inno vation and Competitiveness? Review of Environmental Economics and Policy, 7(1), 2-22. https://doi.org/10.1093/reep/res016

Anselin, L. (1995). Local Indicators of spatial association - LISA, Geographical Analysis, 27, 93-115. 
https://doi.org/10.1111/j.1538-4632.1995.tb00338.x

Arellano, M. \& Bover, O. (1995). Another look at the instrumental-variable estimation of error-components models. Journal of Econometrics, 68, 29-52. https://doi.org/10.1016/0304-4076(94)01642-D

Arrow, K. J. (1962). The economic implications of learning by doing. Review of Economic Studies, 29, 155-172. https://doi.org/10.2307/2295952

Blundell, R. W., \& Bond, S. R. (1998). Initial conditions and moment restrictions in dynamic panel data models. Journal of Econometrics, 87, 115-143. https://doi.org/10.1016/S0304-4076(98)00009-8

Bottazzi, L., \& Peri, G. (2003). Innovation and Spillovers in regions: Evidence from European patent data. European Economic Review, 47, 687-710. https://doi.org/10.1016/S0014-2921(02)00307-0

Bretschger, L., Lechthaler, F., Rausch, S., \& Zhang, L. (2017) Knowledge diffusion, endogenous growth, and the costs of global climate policy. European Economic Review, 93, 47-72. https://doi.org/10.1016/j.euroecorev.2016.11.012

Crow, K. (2015). SHP2DTA: Stata module to convert shape boundary files to Stata datasets. https://ideas.repec.org/c/boc/bocode/s456718.html

European Commission. (2013). The 2013 EU Industrial R\&D Investment Scoreboard, JRC Scientific and Technical Research series. http://iri.jrc.ec.europa.eu/scoreboard.html

Gans, J. S. (2012). Innovation and climate change policy. American Economic Journal: Economic Policy, 4(4), 125-145. https://doi.org/10.1257/pol.4.4.125

Greaker, M. (2003). Strategic environmental policy: Eco-dumping or a green strategy? Journal of Environmental Economics and Management, 45(3), 692-707. https://doi.org/10.1016/S0095-0696(02)00053-0

Hoppmann, J. (2016). The Role of Interfirm knowledge Spillovers for Innovation in Mass-Produced Environmental Technologies. Organization \& Environment. https://doi.org/10.1177/1086026616680683

Jacobs, J. (1969). The economy of cities. Random House, New York.

Kondo, K. (2015). SPGEN: Stata module to generate spatially lagged variables. http://econpapers.repec.org/software/boc/bocode/S458105.html

Kondo, K. (2016). Hot and cold spot analysis using Stata. Stata Journal, 16, 613-631.

Marin, G., \& Lotti, F. (2016). Productivity effects of eco-innovations using data on eco-patents. Industrial and Corporate Change.

Marshall, A. (1890). Principles of economics. Macmillan, London.

Mohr, R. D. (2002). Technical change, external economies and the Porter Hypothesis. Journal of Environmental Economics and Management, 43(1), 158-168. https://doi.org/10.1006/jeem.2000.1166

Moran, P. A. P. (1950). Notes on continuous stochastic phenomena. Biometrika, 37(1/2), 17-23. https://doi.org/10.1093/biomet/37.1-2.17

OECD, REGPAT database. Available online: https://www.oecd.org/sti/inno/40794372.pdf (accessed on 10 May 2017).

Pisati, M. (2008). SPMAP: Stata module to visualize spatial data. https://ideas.repec.org/c/boc/bocode/s456812.html

Porter, M. (1991). America's green strategy. Scientific American, 264, 168. https://doi.org/10.1038/scientificamerican0491-168

Romer, P. M. (1986). Increasing returns and long-run growth, Journal of Political Economy, 94, 1002-1037. https://doi.org/10.1086/261420 


\section{Appendix}

Table A. Distribution of regions by economic area

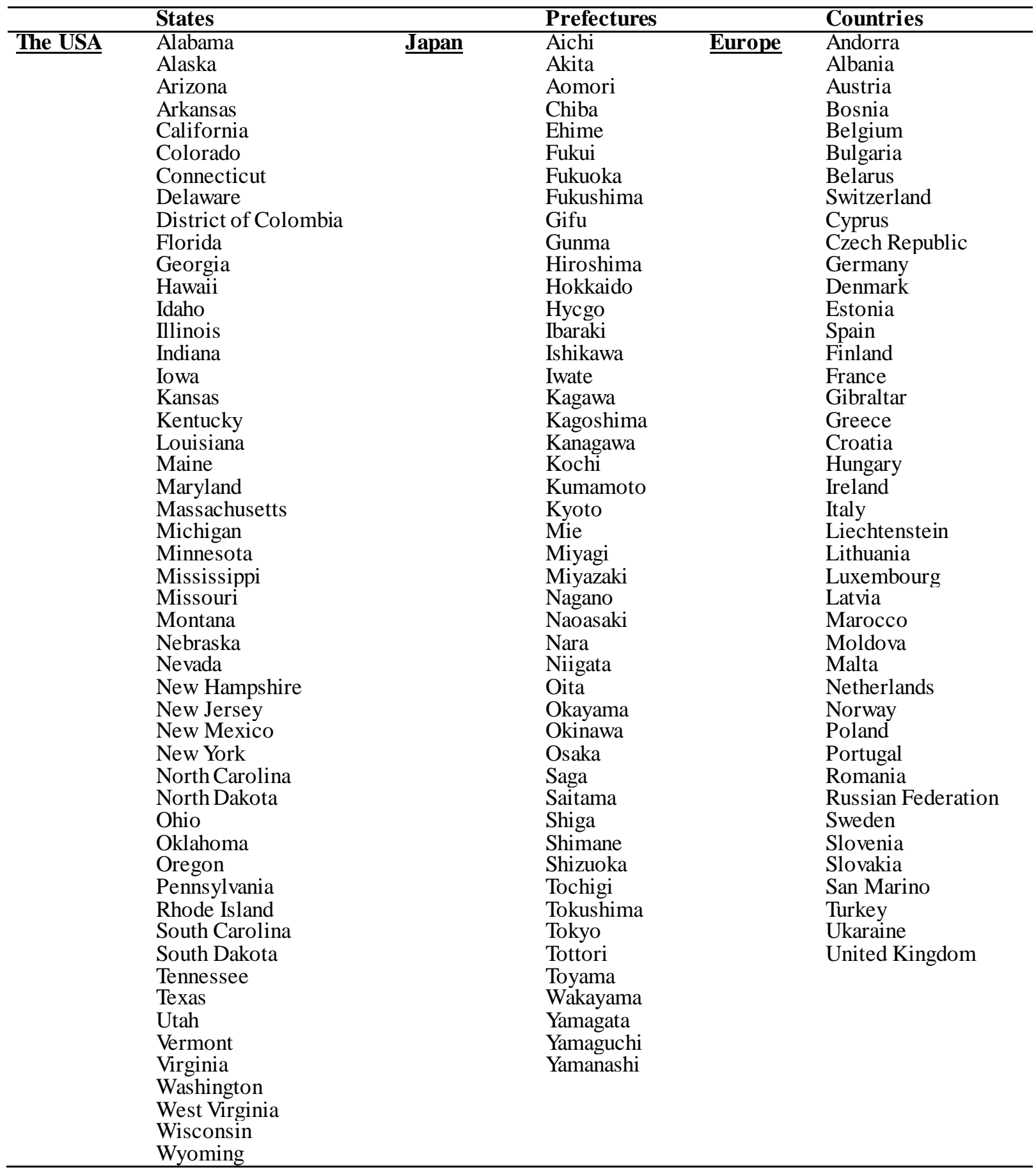

\section{Copyrights}

Copyright for this article is retained by the author(s), with first publication rights granted to the journal.

This is an open-access article distributed under the terms and conditions of the Creative Commons Attribution license (http://creativecommons.org/licenses/by/4.0/). 